\title{
PENGEMBANGAN BUKU AJAR MATEMATIKA MATERI PENJUMLAHAN BILANGAN DESIMAL DENGAN PECAHAN CAMPURAN BERBASIS PENDEKATAN SCIENTIFIC DI SDN 101771 TEMBUNG T.A 2018/2019
}

Elvi Mailani' ${ }^{1}$, Elisa Wulandari ${ }^{2}$

Surel:mailani.elvi@gmail.com

\begin{abstract}
Purpose of this study to determine the validity of mathematics textbooks in the Summation of Decimal Numbers with Scientific Approach Based Fractions in Tembung SDN 101771 FY 2018/2019. : analysis, development, validation, and revision. The subjects of this study were students of VA Elementary School 101771 in Tembung with 32 students with 12 male students and 20 female students. The data collection technique in this study was to use the results of assessments on aspects of the feasibility of content, language, and presentation, interview results, and results of student responses after product trials. The results of this study indicate that textbooks that researchers have developed are declared valid and in accordance with the characteristics of students.
\end{abstract}

Keywords: Textbooks, Valid, Based on a Scientific Approach

\section{ABSTRAK}

Tujuan penelitian ini untuk mengetahui kevalidan buku ajar matematika Materi Penjumlahan Bilangan Desimal Dengan Pecahan Campuran Berbasis Pendekatan Scientific di SDN 101771 Tembung T.A 2018/2019. Subjek penelitian ini adalah siswa-siswi kelas $V^{A}$ SD Negeri 101771 Tembung sebanyak 32 siswa dengan jumlah siswa laki-laki 12 orang dan jumlah siswa perempuan sebanyak 20 orang. Teknik pengumpulan data dalam penelitian ini adalah menggunakan hasil penilaian pada aspek kelayakan isi, bahasa, dan penyajian, hasil wawancara, dan hasil tanggapan siswa setelah ujicoba produk. Hasil penelitian ini menunjukan bahwa buku ajar yang telah peneliti kembangkan dinyatakan valid dan sesuai dengan karakteristik peserta didik.

Kata Kunci: Buku Ajar, Valid, Berbasis Pendekatan Scientific

\section{PENDAHULUAN}

Pendidikan

merupakan

sebuah aktivitas yang sangat penting dalam upaya pengembangan sumber daya manusia dan merupakan kebutuhan dasar bagi seluruh lapisan masyarakat Indonesia yang ingin maju. Pendidikan secara formal dimulai dari jenjang taman kanak- kanak sampai dengan perguruan tinggi merupakan bentuk usaha yang dilakukan oleh manusia dalam upaya meningkatkan kompetensi dan mencari jati diri dari setiap insan. Pendidikan pada masa sekarang ini semakin tergantung pada tingkat kualitas, antisipasi dari para guru untuk menggunakan berbagai sumber 
yang tersedia, dalam upaya mengatasi permasalahan yang dihadapi siswa untuk mempersiapkan pembelajaran yang dapat menumbuhkan cara berfikir siswa menjadi lebih kritis dan kreatif.

Perkembangan dan kemajuan teknologi dewasa ini tidak terlepas dari perkembangan dan kemajuan ilmu pengetahuan.Sejalan dengan perkembangan ilmu pengetahuan tersebut, jadiMatematika sebagai ilmu pengetahuan yang banyak peranannya dalam ilmu lainnya. Sumbangan Matematika terhadap perkembangan ilmu dan teknologi cukup besar, seperti aljabar untuk komputer, numerik untuk teknik, adalah beberapa contoh penggunaan ilmu Matematika dalam bidang ilmu dan teknologi.

Banyak ahli Matematika mengatakan bahwa "Mathematics is the queen as well as the servant of all sciences" Matematika adalah ratu sekaligus pelayan semua ilmu pengetahuan. Sebagai ratu, Matematika seolah-olah bersinggasana di atas semua ilmu karena Matematika berkembang tanpa mendasarkan dirinya pada ilmu-ilmu lainnya.Sebagai pelayan, Matematika melayani ilmu-ilmu lainnya yang menggunakan Matematika dalam penelitian dan pengembangan dirinya.Ungkapan tersebut jelas menggambarkan bahwa ilmu Matematika menduduki posisi sentral dalam kancah dunia ilmu pengetahuan.Untuk dapat memasuki dan menguasai dunia ilmu pengetahuan, kita harus mengenal dan mempelajari Matematika, sekurang-kurangnya pada tingkat dasar dan menengah.

Menurut Mailani (2015:8) "Matematika selalu digunakan oleh bidang ilmu lain seperti fisika, biologi, geografi, sejarah, olah raga, pertanian, kedokteran, arsitektur, arkeologi, listrik atau elektronika, astronomi dan lain-lain. Jadi cukup sulit untuk menemukan suatu profesi atau pekerjaan yang tidak menggunakan

Matematika.Matematika merupakan ilmu dasar yang selalu digunakan dimana saja, kapan saja, dan oleh siapa saja."

Matematika dibutuhkan dalam hampir setiap aspek kehidupan, karena Matematika dapat membentuk pemikir yang kritis, sistematis, logis, kreatif dan memiliki kemauan bekerjasama yang efektif. Matematika diperlukan dalam menghadapi segala perubahan zaman yang terus berubah dan terus berkembang sangat pesat terutama dalam dunia teknologi, seperti yang dicantumkan pada kurikulum 2006 standar kompetensi mata pelajaran Matematika yang dikeluarkan oleh departemen pendidikan nasional disebutkan bahwa: "Matematika itu dimaksudkan pula untuk mengembangkan kemampuan menggunakan Matematika dalam pemecahan masalah dan mengkomunikasikan ide atau gagasan dengan menggunakan simbol, tabel, diagram, dan media lain”. Dengan demikian, siswa perlu memiliki kemampuan memperoleh, 
memilih dan mengelola informasi untuk bertahan pada keadaan yang selalu berubah, tidak pasti dan kompetitif.

Kemampuan tersebut membutuhkan pemikiran kritis, sistematis, logis, kreatif dan memiliki kemauan bekerjasama yang efektif.Cara berpikir seperti ini dapat dikembangkan melalui belajar Matematika karena Matematika memiliki struktur dan keterkaitan yang kuat dan jelas antara konsepnya sehingga memungkinkan siswa terampil berpikir rasional.

Pendidikan Matematika harus bisa mempersiapkan siswa untuk terjun ke dunia kerja.Tujuan pendidikan ini memang dipengaruhi oleh pandangan masyarakat secara umum yang sering menempatkan pendidikan sebagai alat untuk mencari pekerjaan.Pendidikan merupakan suatu bentuk dan sekaligus produk budaya. Oleh karena itu, pendidikan Matematika perlu menempatkan Matematika sebagai hasil kebudayaan manusia dan sekaligus sebagai suatu proses untuk mengembangkan suatu kebudayaan.

Matematika merupakan salah satu cabang ilmu yang sangat penting.Karena pentingnya, Matematika diajarkan mulai dari jenjang SD sampai dengan perguruan tinggi.Sampai saat ini Matematika merupakan salah satu mata pelajaran yang selalu masuk dalam daftar mata pelajaran yang diujikan secara nasional, mulai dari tingkat SD sampai dengan SMA.Bagi siswa selain untuk menunjang dan mengembangkan ilmu-ilmu lainnya, Matematika juga diperlukan untuk bekal terjun dan bersosialisasi dalam kehidupan bermasyarakat.

Tujuan pembelajaran Matematika dalam standar isi yang dikeluarkan oleh Badan Standar Nasional Pendidikan (BSNP) menunjukkan bahwa penguasaan Matematika tidak hanya sebatas penguasaan fakta dan prosedur Matematika serta pemahaman konsep, tetapi juga berupa kemampuan proses Matematika siswa seperti pemecahan masalah, penalaran, komunikasi dan koneksi Matematika. Semuanya harus saling menunjang dalam proses pembelajaran Matematika sehingga siswa dapat menguasai Matematika secara utuh.

Menurut Puji (2014:1) "Matematika merupakan salah satu pelajaran yang secara formal diberikan kepada siswa sejak kelas 1 SD. Namun, masih banyak siswa kelas 4, 5, maupun 6 yang masih kesulitan menyelesaikan soal-soal Matematika. Tidak jarang diantara mereka yang mengerjakan dengan asal-asalan atau bahkan mencontek lantaran kurang mahir dalam Matematika.Padahal, jika siswa mempersiapkan diri sebaik-baiknya, berbagai masalah di atas tidak akan terjadi”.

Berdasarkan hasil observasi peneliti di SDN 101771 Tembung, ditemukan bahwa pembelajaran di sekolah masih menggunakan buku pelajaran Matematika yang belum 
berbasis saintifik. Sedangkan sekolah tersebut sudah menerapkan kurikulum 2013, namun buku yang digunakan belum berbasis saintifik. Hal ini menyebabkan siswa bersifat pasif (bersifat menerima) tentang apa yang dipelajari.

\section{Sebenarnya Matematika}

menurut Peraturan Menteri Pendidikan dan Kebudayaan Nomor 24 Tahun 2016 bahwa mata pelajaran Matematika itu sudah terpisah dari mata pelajaran lain. Akan tetapi pada sekolah tersebut, buku-buku yang digunakan dalam proses belajar mengajar masih kurang memadai jumlah bukunya dan materi yang ada di dalamnya juga kurang detail dalam penyajiannya khususnya materi penjumlahan bilangan desimal dengan pecahan campuran. Jadi dari itu, peneliti ingin mengembangkan sebuah buku ajar materi penjumlahan bilangan desimal dengan pecahan campuran berbasis pendekatan saintifik agar tersusun dengan baik, lengkap dengan cara kerjanya serta dilengkapi beberapa contoh-contoh untuk mempermudah siswa dalam mempelajari materi tersebut.

Peneliti juga melihat bahwa hanya 1 orang siswa yang mencapai nilai Kriteria Ketuntasan Maksimal (KKM) yaitu nilai 75 , dan 4 orang siswa hampir mencapai nilai Kriteria Ketuntasan Maksimal (KKM) yaitu memperoleh nilai 70. Hal ini dikarenakan kelima siswa tersebut termasuk kategori siswa yang mampu menyelesaikan tugas Matematika yang diberikan oleh guru.Namun, mereka membutuhkan waktu yang lama untuk menjawabnya. Sedangkan, siswa yang lain memperoleh nilai jauh di bawah Kriteria Ketuntasan Maksimal (KKM) yaitu nilai 55-65 saja. Karena mereka tidak paham sama sekali cara menyelesaikan penjumlahan bilangan desimal dengan pecahan campuran. Hal ini juga dikarenakan buku pegangan siswa yang tidak dilengkapi dengan cara kerjanya serta contoh-contoh soal tidak dilampirkan dalam materi tersebut. Buku-buku yang mereka gunakan hanya dilengkapi dengan soal-soal untuk menguji kemampuan mereka.Pada akhirnya, setelah siswa diminta untuk mengerjakan soal-soal tersebut tidak banyak dari mereka yang memperoleh nilai bagus.Di samping itu, penggunaan buku ajar Matematika belum tertata dengan baik, cenderung hanya memperhatikan struktur perkembangan kognitif anak.

Jumlah buku ajar yang tersedia sangat banyak dengan kualitas yang berbeda.Dalam penyusunan buku ajar ini harus disesuaikan dengan karakteristik siswa dan tujuan pembelajaran. Dalam Peraturan Menteri Pendidikan dan Kebudayaan Nomor 65 Tahun 2013 tentang standar proses dinyatakan bahwa proses pembelajaran saat ini menggunakan pembelajaran dengan pendekatan saintifik, terpadu dan tematik.

Maka dalam kajian penelitian ini, desain pengembangan buku ajar dilakukan melalui pendekatan saintifik. Pendekatan saintifik 
merupakan pendekatan pembelajaran yang berorientasi atau berpusat pada siswa (student centered approach) dan dilakukan dengan lima langkah pembelajaran yang relevan dengan teori belajar Bruner, Piaget, dan Vygotsky yaitu tahap mengamati, bertanya, mengumpulkan informasi, mengasosiasi dan mengkomunikasikan. Kelima tahap ini dipandang mampu menghantarkan peserta didik meningkatkan kemampuan ilmiah, keterampilan berpikir, merasa dan melakukan.Pendekatan saintifik diperoleh urutan yang logis dan sistematis, artinya guru mengajarkan materi ajar secara hirarki dan saling berhubungan. Pengorganisasian isi materi buku ajar melalui model analisis tugas akan mengarahkan siswa kepada upaya untuk mengamati, menanya, mengumpulkan, mengasosiasi, mengkomunikasikan dan menciptakan cara belajarnya sendiri.

\section{METODE PENELITIAN}

\section{Jenis Penelitian}

Penelitian ini termasuk penelitian pengembangan.Dalam penelitian ini yang dikembangkan berupa buku ajar. Proses pengembangan berkaitan dengan kegiatan pada setiap tahap-tahap pengembangan. Produk akhir dievaluasi berdasarkan aspek kualitas produk yang ditetapkan. Dengan demikian yang menjadi produk penelitian ini adalah buku ajar berbasis pendekatan scientific yang validdan sesuai karakteristik peserta didik.

Penelitian ini rencananya akan dilakukan di SDN 101771 Tembung. Waktu penelitian pengembangan(Developmental research) ini dilakukan pada bulan Januari-Maret Tahun ajaran 2018/2019 pada semester genap.Subjek penelitian ini adalah siswa kelas V.A SDN 101771 Tembung.Dalam kelas ini terdiri dari 32 siswa yang terdiri dari 20 siswa perempuan dan 12 siswa lakilaki. Penelitian ini dibantu oleh beberapa ahli Matematika sebagai validator , dimana ahli tersebut adalah guru kelas V.B dan beberapa dosen yang ada di Unimed yang memiliki keahlian dibidang Matematika untuk menguji kevalidan buku yang peneliti kembangkan.

Dalam penelitian ini, data yang diambil sebagai berikut: 1) hasil penilaian pada aspek kelayakan isi dan kelayakan penyajian yang diperoleh dari Ibu Dra. Masta Ginting, M.Pd, Bapak Drs. Daitin Tarigan, M.Pd dan Bapak Andri Kristianto Sitanggang, S.Pd, M.Pd,2) hasil wawancara yang diperoleh dari guru kelas VA setelah menggunakan buku yang dikembangkan peneliti dalam kegiatan belajar mengajar Matematika, dan 3) data tanggapan siswa yang diperoleh dari uji coba buku yang telah dikembangkan.

Instrument pengumpulan data pada penelitian pengembangan ini adalah instrument penilaian produk yang telah dikembangkan peneliti.Instrument pokok yang 
dipakai untuk mengumpulkan data dalam pengembangan ini adalah uji validasi buku yang berbasis pendekatan scientific.Tujuannya untuk memperoleh data kualitatif dan kuantitatif demi kesempurnaan dan kelayakan produk hasil pengembangan.

Data yang diperoleh kemudian dianalisis. Teknik analisis data yang digunakan dalam penelitian ini adalah teknik analisis deskriptif meliputi: 1) validasi buku ajar yang digunakan dalam pembelajaran. Dalam hal ini validasi buku ajar dilakukan oleh ahli materi Matematika dari Unimed dan guru bidang studi Matematika dengan memberikan lembar validasi yang telah dirancang sebelumnya, 2) aplikasi penggunaan buku yang telah dikembangkan oleh peneliti dalam proses pembelajaran Matematika materi penjumlahan bilangan desimal dan pecahan campuran. Untuk menentukan persentase tersebut dapat dipergunakan rumus sebagai berikut:

$P=\frac{\sum x}{\sum x i} x 100 \%$

(Arikunto, 2003)

Keterangan:

$\mathrm{P}$ : Persentase Kelayakan

$\mathrm{X}$ : Jumlah skor jawaban validator (nilai nyata)

$\mathrm{X}_{\mathrm{i}}$ : Jumlah Skor jawaban tertinggi (nilai harapan)

\section{HASIL DAN PEMBAHASAN}

Hasil dari pengembangan buku ajar ini ialah terciptanya sebuah buku ajar Matematika berbasis pendekatan scientific kelas V SD semester II hasil dari pengembangan materi-materi Matematika untuk kelas V SD/MI. Pengembangan buku ajar Matematika kelas V semester II ini dilakukan setelah melalui proses perbaikan-perbaikan tulisan yang mencakup isi di mana validator memberikan saran yang sudah baik tidak perlu di revisi, namun pada bagian latihan dan tes validator memberikan saran bahwa soal yang ada di nomor 8, 39 dan 44 masih kurang jelas bentuk pengerjaannya begitu juga dengan kelayakan penyajian. Pada aspek kelayakan bahasa, validator juga memberi saran yang sudah baik untuk buku ajar yang dikembangkan, serta validator menginginkan peneliti untuk mempertahankan upaya yang sudah ada. Berdasarkan tahapan yang sudah diperbaiki mengikuti saran yang diberikan oleh validator terhadap kelayakan isi, kelayakan penyajian dan kelayakan bahasa menurut Ibu Dra. Masta Ginting, M.Pd, Bapak Drs. Daitin Tarigan, M.Pd dan Bapak Andri Kristianto Sitanggang, S.Pd., M.Pd, jadi buku ajar yang dikembangkan sudah memperoleh hasil penilaian baik dan layak digunakan untuk proses pembelajaran.

Berdasarkan proses penelitian yang telah dilakukan melalui pengisian angket untuk standarisasi buku ajar yang dikembangkan guna memperoleh informasi-informasi 
perbaikan jadi di peroleh data-data penelitian untuk kelayakan buku berupa kelayakan isi, kelayakan penyajian dan kelayakan bahasa. Setelah memperoleh informasi kelayakan buku jadi dilakukan perbaikan untuk seluruh aspek buku tersebut lalu di nilai kembali oleh guru sehingga memenuhi standarisasi BSNP. Setelah buku yang dikembangkan memperoleh penilaian dari guru dan telah dikategorikan layak, jadi dilakukanlah uji coba buku dengan diajarkan kepada siswa kelas VA untuk memperoleh hasil dari pengaruh buku terhadap proses belajar siswa di dalam kelas.

Berdasarkan hasil analisis buku ajar yang telah dikembangkan dan telah divalidkan oleh beberapa validator tersebutjadi diperoleh datadata penelitian yang dapat dijelaskan sebagai berikut:

\section{Standarisasi Kelayakan Isi Buku}

Berdasarkan hasil analisis kelayakan isi buku dari dosen MatematikaBapak Andri Kristianto Sitanggang, S.Pd., M.Pd di peroleh keunggulan dari buku Matematika yang telah dikembangkan ini berupa:

1. Kelengkapan materi dipandang baik dan menggambarkan secara keseluruhan materi dengan jelas.

2. Keluasan materi dipandang lengkap dan mencerminkan seluruh materi Matematika semester dua di sertai dengan petunjuk kegiatan untuk siswa dapat belajar.

3. Materi yang disajikan cukup sesuai dengan kedalaman materi Matematika yang dibutuhkan siswa untuk kelas V. Materi Matematika yang dituangkan dalam buku mencakup prinsipprinsip yang harus dituangkan sesuai KD dan KI K.13

4. Fakta yang disajikan dalam buku sesuai dengan materi yang diajarkan.

5. Konsep Matematika yang disajikan cukup akurat dan mudah dimengerti.

6. Prinsip Matematika disajikan dengan sesuai.

7. Prosedur percobaan dalam buku sangat baik.

8. Teori yang dituangkan dalam buku telah sangat sesuai dengan judul materi dalam buku.

9. Keterkaitan teori dengan konsep disajikan dengan sesuai dengan isi pembahasan.

10. Menyajikan uraian serta contoh dalam setiap konsep yang disajikan dengan baik.

11. Buku mengandung wawasan produktifitas yang baik.

12. Setiap isi disajikan dengan petunjuk agar siswa berpikir kreatif dan produktif sehingga merangsang keingintahuan.

13. Isi buku mengarahkaan siswa agar memperoleh soft skill yang baik.

Hasil analisis buku ini bertujuan untuk menunjukkan besarnya kelayakan isi buku menurut penilaian dosen yang telah sangat berpengalaman dalam mengajarkan mata pelajaran Matematika di sekolah setingkat dengan sekolah menengah atas (SMA) dan jenjang perguruan tinggi. 
Berdasarkan hasil pengembangan buku diperolehlah skor sebesar 58 atau sebesar $96,66 \%$ pada standarisasi kelayakan isi buku. Jadi buku ini termasuk kedalam kategori baik dan dianggap sudah validuntuk kelayakan isi sehingga tidak perlu dilakukan revisi terhadap isi buku ajar Matematika kelas V semester II ini.

\section{Standarisasi Kelayakan Penyajian Buku}

Standarisasi kelayakan penyajian oleh Ibu Dra. Masta Ginting, M.Pd ini dilakukan sebagai upaya untuk mengetahui tingkat penyajian materi yang disajikan dalam buku yang dikembangkan oleh peneliti untuk keperluan siswa kelas V semester II.

Berdasarkan hasil penilaian yang telah dilakukan bahwa aspek dari kelayakan penyajian ini mendapat skor 3 atau 4 dan memperoleh hasil yang sangat baik yang itu sebesar 81 atau sebesar 92,04\% dengan demikian jadi untuk kelayakan penyajian di dalam buku dianggap telah sangat baik atau sangat validsehingga tidak perlu direvisi.

\section{Standarisasi Kelayakan Bahasa Buku}

Bahasa $\begin{gathered}\text { adalah } \\ \text { komunikasi dengan }\end{gathered}$ sesama
manusia.Sebagai makhluk sosial
bahasa memiliki peran yang sangat
penting dalam membentuk hubungan
baik di dalam kehidupan

bermasyarakat. Penggunaan bahasa yang sulit dimengerti atau memiliki makna ganda akan menyebabkan timbulnya kesalahpahaman di dalam kehidupan sosial. Bila diaplikasikan dalam buku yang memuat materimateri pelajaran jadi kesalahan menggunakan bahasa yang baik dan benar akan menyebabkan kesulitan pembaca mengerti akan isi buku dan materi yang diajarkan sehingga sangtalah penting penggunaan bahasa yang baik agar tidak menyebabkan kesulitan dalam memahami atau mengerti akan isi buku yang telah dikembangkan.

Berdasarkan hasil analisis terhadap isi kelayakan bahasa yang dilakukan oleh Bapak Drs. Daitin Tarigan, M.Pd terhadap buku ajar kelas V semester II yang dikembangkan di peroleh hasil yang sangat baik yang itu sebesar 38 atau sebesar 95\%. Hal ini berarti buku sudah dianggap validdan tidak perlu dilakukan revisi dalam penggunaan bahasanya.

\section{SIMPULAN}

Berdasarkan rumusan tujuan hasil penelitian dan pembahasan pada penelitian pengembangan buku ajar Matematika berbasis pendekatan scientific yang dikemukakan pada bab sebelumnya, jadi dapat disimpulkan sebagai berikut:

1. Berdasarkan hasil penilaian tentang kelayakan isi yang dilakukan oleh Bapak Andri Kristianto Sitanggang, S.Pd., M.Pd buku ajar Matematika kelas V SD berbasis pendekatan 
Elvi M, Dkk: Pengembangan Buku Ajar...

scientific dikategorikan layak atau validkarena memperoleh hasil sebesar 96,66\%. Dengan begitu untuk isi pada buku ini tidak perlu dilakukan revisi.

2. Berdasarkan hasil penilaian tentang kelayakan penyajian yang dilakukan oleh Ibu Dra. Masta Ginting, M.Pd buku ajar Matematika kelas V SD berbasis pendekatan scientific dikategorikanvalidkarena memperoleh hasil nilai sebesar 81 atau sebesar 92,04\%. Dengan begitu untuk penyajian pada buku ini tidak perlu dilakukan revisi.

3. Berdasarkan hasil penilaian tentang kelayakan bahasa yang dilakukan oleh Bapak Drs. Daitin Tarigan, M.Pd buku ajar Matematika kelas V SD berbasis pendekatan scientific dikategorikan layak atau validdan sesuai dengan karakteristik peserta didik karena memperoleh hasil sebesar 95\%. Dengan begitu untuk penggunaan bahasa pada buku ini tidak perlu direvisi.

\section{DAFTAR RUJUKAN}

Agustini Melyda Rahman. 2018. "Pengembangan Buku Ajar Penulisan Artikel Jurnal Untuk Peningkatan Keruntutan Berpikir Dalam Berargumentasi Pada Mahasiswa Program Studi PBSI Program Magister". Yogyakarta: Universitas Sanata Dharma
Akbar. S. 2013. "Instrumen Perangkat Pembelajaran”. Bandung: Remaja.

Arifin, Syamsul. Dkk. 2008."Sukses Menulis Buku Ajar Dan Referensi". Surabaya:Grasindo. Gultom, Syawal. 2010. "Matematika Kompeten Berhitung untuk Sekolah Dasar Kelas V'. Bandung: Citapustaka Media Perintis.

Hendriana, Heris. dkk. 2014. "Penilaian Pembelajaran Matematika". Bandung: Refika Aditama.

Hidayat, Anto. 2016.

"Pengembangan Buku Ajar Matematika Berbasis Saintifik Pada Konsep Pecahan di Kelas IV SD”. Disertasi dan Tesis Program Pascasarjana UM.

Kurniasih, Imas. 2014. "Sukses Implemntasi Kurikulum 2013”. Yogyakarta: Kata Pena.

Lazim. M. 2013. "Penerapan Pendekatan Saintifik dalam Pembelajaran Kurikulum 2013”. Yogyakarta: PT3K Seni dan Budaya Yogyakarta

Mailani, Elvi. 2015. "Penerapan Pembelajaran Matematika Yang Menyenangkan”. Elementary School Journal Pgsd Fip Unimed, 1 (1).

Muslich, M. 2015. "Textbook Writing: Dasar-dasar pemahaman, penulisan dan pemakaian buku teks". Yogyakarta: Ar Ruzz Media.

Prastowo. A. 2018. "Panduan Kreatif Membuat Bahan Ajar 
Inovatif". Yogyakarta: Diva Press. , 2014. "Panduan

Kreatif Membuat Bahan Ajar Inovatif". Yogyakarta: Diva Press.

Puspita, Nella Ratih. 2018. "Pengembangan Buku Ajar Berbasis Pendekatan Saintifik Sebagai Bahan Ajar Mata Pelajaran Akutansi Perbankan Syariah Pada Siswa SMK Kompetens Keahlian Perbankan Syariah". Jurnal Pendidikan Akuntansi. 6 (2)

Rahayu, Ari Ramayanti. 2016. "Pengembangan Buku Ajar Biologi SMA Berbasis Pendekatan Saintifik Untuk Kelas XI Semester II". Jurnal pendidikan. 13 (3)

Slamet, Widodo. 2015. "Pengembangan Buku Ajar Matematika dengan Pendekatan Scientific Kelas VII Semester II sebagai Upaya Meningkatkan Hasil Belajar Siswa". Skripsi

Sufairoh. 2016. "Pendekatan Saintifik \& Model Pembelajaran Kurikulum 2013". Jurnal Pendidikan Profesional 5 (3).

Trianto. 2011. "Mendesain Model Pembelajaran Inovatif Progresif". Jakarta: Kencana Predana Media Group

Wahyu, Yoppy Purnomo. 2015. "Pembelajaran Matematika Untuk PGSD". Jakarta: Erlangga.
Wati, Erma. 2016. "Pengembangan Buku Ajar Tematik Berbasis Saintifik Sub Tema Hidup Bersih dan Sehat di Sekolah Untuk Siswa Kelas II SDN Bendogerit I Kota Blitar'. Disertasi dan Tesis Program Pascasarjana Um.

Yahya, Yusuf. Dkk. 2010."Matematika Dasar Perguruan Tinggi". Bogor: Ghalia Indonesia

Yulida. 2018. "Hubungan Antara Penggunaan Media Visual Dalam Pembelajaran Matematika Dengan Hasil Belajar Siswa Kelas IV Sdn 200103 Padang Sidimpuan". Skripsi. Medan: Unimed. 